\title{
Consequences and therapy of the metabolic acidosis of chronic kidney disease
}

\author{
Jeffrey A. Kraut • Nicolaos E. Madias
}

Received: 26 February 2010 /Revised: 22 April 2010 /Accepted: 4 May 2010 /Published online: 5 June 2010

(C) The Author(s) 2010. This article is published with open access at Springerlink.com

\begin{abstract}
Metabolic acidosis is common in patients with chronic kidney disease (CKD), particularly once the glomerular filtration rate (GFR) falls below $25 \mathrm{ml} / \mathrm{min} / 1.73 \mathrm{~m}^{2}$. It is usually mild to moderate in magnitude with the serum bicarbonate concentration $\left(\left[\mathrm{HCO}_{3}{ }^{-}\right]\right)$ranging from 12 to $23 \mathrm{mEq} / \mathrm{l}$. Even so, it can have substantial adverse effects, including development or exacerbation of bone disease, growth retardation in children, increased muscle degradation with muscle wasting, reduced albumin synthesis with a predisposition to hypoalbuminemia, resistance to the effects of insulin with impaired glucose tolerance, acceleration of the progression of CKD, stimulation of inflammation, and augmentation of $\beta_{2}$-microglobulin production. Also, its presence is associated with increased mortality. The administration of base to patients prior to or after initiation of dialysis leads to improvement in many of these adverse
\end{abstract}

\section{J. A. Kraut}

Medical and Research Services, VHAGLA Healthcare System,

UCLA Membrane Biology Laboratory,

Los Angeles, CA, USA

\section{J. A. Kraut}

Division of Nephrology, VHAGLA Healthcare System,

Los Angeles, USA

J. A. Kraut

David Geffen School of Medicine,

Los Angeles, CA, USA

\section{N. E. Madias $(\bowtie)$}

Division of Nephrology, Department of Medicine,

St. Elizabeth's Medical Center,

736 Cambridge St.,

Boston, MA 02135, USA

e-mail: nicolaos.madias@caritaschristi.org

N. E. Madias

Department of Medicine, Tufts University School of Medicine, Boston, MA, USA effects. The present recommendation by the National Kidney Foundation Kidney Disease Outcomes Quality Initiative (NKF KDOQI) is to raise serum $\left[\mathrm{HCO}_{3}{ }^{-}\right]$to $\geq 22 \mathrm{mEq} / \mathrm{l}$, whereas Caring for Australians with Renal Impairment (CARI) recommends raising serum $\left[\mathrm{HCO}_{3}{ }^{-}\right]$to $>22 \mathrm{mEq} / \mathrm{l}$. Base administration can potentially contribute to volume overload and exacerbation of hypertension as well as to metastatic calcium precipitation in tissues. However, sodium retention is less when given as sodium bicarbonate and sodium chloride intake is concomitantly restricted. Results from various studies suggest that enhanced metastatic calcification is unlikely with the $\mathrm{pH}$ values achieved during conservative base administration, but the clinician should be careful not to raise serum $\left[\mathrm{HCO}_{3}{ }^{-}\right]$to values outside the normal range.

Keywords Bicarbonate therapy - Bone disease .

Chronic kidney disease $\cdot$ Dialysis $\cdot$ Metabolic acidosis

\section{Introduction}

Metabolic acidosis is a common complication of chronic kidney disease (CKD), usually appearing when glomerular filtration rate (GFR) falls below $25 \mathrm{ml} / \mathrm{min} / 1.73 \mathrm{~m}^{2}$ $[1,2]$. It is usually mild to moderate in degree (serum bicarbonate ${ }^{-}$concentration $\left.\left[\mathrm{HCO}_{3}{ }^{-}\right] 12-23 \mathrm{mEq} / \mathrm{l}\right)$. However, despite its lack of severity, it can have an adverse impact on cellular function and contribute to increased morbidity and mortality $[1,3,4]$.

In the present review, we briefly describe the pathogenesis of metabolic acidosis of CKD and the associated clinical and laboratory findings. We then highlight the adverse effects of chronic metabolic acidosis and their pathogenesis as well as the indications, goals, and potential complications of therapy. 


\section{Pathogenesis of the metabolic acidosis of CKD}

Approximately $1 \mathrm{mEq} / \mathrm{kg}$ body weight (b. wt.) of endogenous net acid is produced each day in adults with normal renal function, primarily from the metabolism of ingested protein [5]. Endogenous net acid production in infants and children is more variable, averaging $1-3 \mathrm{mEq} / \mathrm{kg}$ b. wt. per day [6]. This higher level is attributed, in part, to the consumption of base by growing tissues, primarily bone [7]. In post-pubertal individuals, endogenous net acid production is similar in magnitude to that of adults.

To maintain acid-base balance, the renal tubules must quantitatively reabsorb the daily filtered $\mathrm{HCO}_{3}{ }^{-}$load (approx. $4500 \mathrm{mEq}$ in adults with normal renal function). In addition, they must synthesize sufficient $\mathrm{HCO}_{3}{ }^{-}$to neutralize endogenous net acid. The result of these processes is to maintain serum $\left[\mathrm{HCO}_{3}{ }^{-}\right]$within a very narrow range.

Metabolic acidosis can result from an increase in endogenous net acid production, an increase in urinary or gastrointestinal $\mathrm{HCO}_{3}{ }^{-}$excretion, or a decrease in renal synthesis of $\mathrm{HCO}_{3}{ }^{-}$manifesting as reduced urinary ammonium and net-acid excretion. Endogenous net acid production in patients with CKD is equal to or even slightly lower than that in individuals with normal renal function $[8,9]$, excluding this as a factor in the genesis of metabolic acidosis. In a minority of patients, there is sufficient urinary bicarbonate loss to contribute to the prevailing hypobicarbonatemia [10, 11]. However, in most patients, urinary bicarbonate loss is minimal, and the metabolic acidosis develops because new bicarbonate synthesis is less than endogenous net acid production [11]. This limitation in bicarbonate synthesis renders the patient with CKD more vulnerable to developing hypobicarbonatemia than normal individuals, both in the presence or absence of an increase in endogenous net acid or an increase in gastrointestinal $\mathrm{HCO}_{3}{ }^{-}$excretion.

Once hypobicarbonatemia has ensued, serum $\left[\mathrm{HCO}_{3}{ }^{-}\right]$ remains stable as long as renal function does not decline further or there is no increase in endogenous net acid production or gastrointestinal bicarbonate loss. Results from carefully controlled studies suggest that the stability of serum $\left[\mathrm{HCO}_{3}{ }^{-}\right]$occurs despite continuing positive $\mathrm{H}^{+}$balance [12], an effect attributed to buffering by bone [12-14].

The thesis that patients with CKD and metabolic acidosis are in positive $\mathrm{H}^{+}$balance has been challenged. Using balance techniques, some investigators have concluded that patients with CKD and stable hypobicarbonatemia are in neutral acid-base balance [8]. At this point, it is not possible to reconcile these discrepant results.

Because bone is considered to be an important buffering component, it has been postulated that the bone disease commonly present in patients with CKD may be associated with a depletion of bone buffers and thereby lessen total body buffering capacity. However, in one study in which this concept was tested in dialysis patients, the apparent bicarbonate space, a reflection of non-bicarbonate buffering capacity, was similar to that of normal individuals [9].

\section{Clinical and laboratory characteristics}

Observational studies have shown that metabolic acidosis generally develops when the GFR falls below $25 \mathrm{ml} / \mathrm{min} /$ $1.73 \mathrm{~m}^{2}[1,2,15]$. However, it can appear earlier in the course of CKD [16], particularly if additional defects in tubular acid excretion are present as, for example, when hyporeninemic hypoaldosteronism or anatomical damage to the collecting duct is present [17].

The hypobicarbonatemia is usually mild to moderate in degree, with serum $\left[\mathrm{HCO}_{3}{ }^{-}\right]$varying between 12 and $23 \mathrm{mEq} / 1[2,18]$. Severe metabolic acidosis in the absence of a substantial increase in endogenous net acid production or bicarbonate losses is unusual. In general, the severity of the hypobicarbonatemia correlates with the level of GFR, with the serum $\left[\mathrm{HCO}_{3}{ }^{-}\right]$being lower at lower GFR values. However, serum $\left[\mathrm{HCO}_{3}{ }^{-}\right]$can be only minimally reduced despite severe renal failure $\left(\mathrm{GFR}<15 \mathrm{ml} / \mathrm{min} / 1.73 \mathrm{~m}^{2}\right)$ [19]. The reasons for the variability in the onset and severity of metabolic acidosis are not well understood. Because renal acid excretion is primarily a tubular function, such variability may reflect differences in tubular function in the presence of similar levels of GFR. An additional contributing factor may be differences in dietary protein intake, the major contributor to the endogenous net acid load.

The anion gap in patients with the metabolic acidosis of CKD can be elevated (normochloremic acidosis) or normal (hyperchloremic acidosis) [1]. It had been suggested that a normal anion gap pattern characterizes early CKD, subsequently evolving into a high anion gap pattern as the GFR falls [16]. However, several studies have shown that a normal anion gap pattern can occur in all stages of renal failure [16, 19]. The explanation for this conundrum is unclear. Nonetheless, a predominately normal anion gap pattern is more common in patients with hyporeninemic hypoaldosteronism or anatomical damage to the collecting duct [20], findings suggesting that the presence of an additional renal tubular dysfunction may be an important factor [1, 20].

It appears that the anionic pattern of the metabolic acidosis does not have any influence on the nature or severity of the associated adverse effects. Moreover, since the accumulating anions are primarily inorganic in nature and therefore not potential sources of base, the electrolyte pattern does not have any bearing on the quantity of base required to raise serum $\left[\mathrm{HCO}_{3}{ }^{-}\right]$by a given amount. 


\section{Adverse effects of metabolic acidosis}

The effects of metabolic acidosis on cellular function have been examined in vitro using cultured cells or isolated tissues [13], and in vivo studying animals and humans with normal or compromised renal function [1]. In humans with $\mathrm{CKD}$, the adverse effects of metabolic acidosis have been examined in patients before or after initiation of chronic maintenance dialysis [14, 21-29]. A limitation of the studies performed in adults with metabolic acidosis, whether due to CKD or other causes, is that only a few of them feature a randomized controlled design and most involve small numbers of subjects [30]. Similarly, there have been no randomized controlled studies in children. Therefore, conclusions about adverse effects and the benefits of base therapy are largely based on observational studies. The major adverse effects of chronic metabolic acidosis on cellular function are shown in Table 1 and are discussed below.

Development or exacerbation of bone disease and impaired growth in children

The bone disease of CKD is due to alterations in parathyroid hormone (PTH) levels, low vitamin D levels and, in some cases, the effects of certain toxins, such as aluminum [31]. However, a substantial quantity of data has accrued to implicate chronic metabolic acidosis as an additional important factor [1, 14].

In vitro studies using cultured bone cells or isolated calvariae and in vivo studies in animals have demonstrated that prolonged metabolic acidosis can directly stimulate osteoclast-mediated bone resorption and inhibit osteoblastmediated bone formation [13, 14, 32, 33]. Also, some, but not all, animal and human studies have shown that metabolic acidosis can reduce vitamin D levels from what is necessary for normal bone formation [34, 35].

PTH secretion is stimulated by chronic metabolic acidosis in humans [36]. On the other hand, metabolic acidosis attenuates the cellular response to PTH, as

Table 1 Adverse effects of chronic metabolic acidosis

Development or exacerbation of bone disease

Growth retardation in children

Increased degradation of muscle with muscle wasting

Reduction in albumin synthesis

Acceleration of progression of kidney disease

Impairment of glucose tolerance

Abnormal thyroid functions

Increased $\beta_{2}$-microglobulin production

Stimulation of inflammation

Development of cardiovascular disease and increased mortality measured by cAMP accumulation in rat tissues [37]. The final effect of acidosis on the cellular response to metabolic acidosis will be the sum of these counterbalance effects. The actions of the calcium sensing receptor might also be attenuated by a decrease in extracellular $\mathrm{pH}$, perhaps contributing to an increase in PTH levels [38].

In animals, prolonged metabolic acidosis (for many months) can produce osteoporosis or exacerbate the osteitis fibrosis cystica of CKD [13, 34, 39]. Individual case reports or small studies in patients with CKD revealed worsening of osteomalacia or osteitis fibrosa cystica in the presence of metabolic acidosis [40-43].

In adults on chronic maintenance hemodialysis, amelioration of the acidosis by raising the dialysate base concentration was found to attenuate the rise in PTH, reduce bone resorption, and improve bone formation [29]. In another study in dialysis patients, correction of the acidosis restored the normal suppression of PTH secretion in response to infused calcium [28]. In children with proximal renal tubular acidosis (RTA), but normal or minimally impaired renal function, bone histomorphometric studies revealed low bone formation and mineralization, which improved following correction of the acidosis with base therapy [44]. In another study, bone mineral density was reduced in children with epilepsy given a ketogenic diet that produced mild metabolic acidosis (mean serum $\left.\left[\mathrm{HCO}_{3}{ }^{-}\right] 21.9 \pm 1.9 \mathrm{mEq} / \mathrm{l}\right)[45]$.

In addition to the effects of metabolic acidosis on the bone described above, metabolic acidosis alters the longitudinal growth of children. Thus, in the study described above, longitudinal growth of the children was impaired. Growth was also stunted in children with distal RTA, subsequently improving following correction of the acidosis [46, 47].

In studies designed to examine the mechanism underlying the impaired growth, young rats were subject to chronic metabolic acidosis for 14 days. This resulted in stunted longitudinal growth and reduced growth plate height [48]. Both cartilage production and bone formation were decreased, albeit at different intensities, resulting in the shortened growth plate. This effect of acidosis on growth could be due to inhibition of the secretion of growth hormone or its actions on peripheral tissues [49]. In support of the latter hypothesis, it has been shown that metabolic acidosis prevents the beneficial effect of growth hormone treatment on the growth of uremic rats [50]. Furthermore, low serum concentrations of insulin-like growth factor 1 (IGF-1) and low hepatic levels of growth hormone receptor and IGF-1 receptor mRNAs have been reported in rats with metabolic acidosis [51]. Also, administration of IGF-1 does not accelerate the growth of acidotic rats, findings supporting the thesis that a peripheral mechanism at the level of target tissues is responsible for the resistance to the growthpromoting actions of growth hormone or IGF-1 [52]. 
Thus, although controlled studies of the impact of correction of metabolic acidosis alone on the growth in children with CKD are not available, metabolic acidosis is considered to be a contributory factor to short stature in children with CKD prior to or after initiation of chronic maintenance dialysis. Therefore, it is recommended that it be corrected prior to the initiation of growth hormone therapy [49].

Taken as a whole, the studies cited above indicate that metabolic acidosis can be a contributory factor to the development or exacerbation of bone disease in both adults and children and that it can impair growth in children with or without CKD. Direct effects of an acidic milieu on bone and indirect effects mediated by changes in PTH levels and/or its actions or vitamin D levels appear to contribute to these pathological effects.

How severe the metabolic acidosis must be to produce bone disease is not clear. In post-menopausal women with age-related osteoporosis who had normal renal function and normal acid-base parameters, ingestion of sufficient base to neutralize endogenous acid production improved the biomarkers of bone metabolism [53]. These data suggest that even the normal endogenous acid load, if left unneutralized, can have harmful effects on bone. Moreover, it seems reasonable to extrapolate from these findings that any hypobicarbonatemia resulting from retention of the endogenous acid load would be harmful. In this regard, evaluation of more than 1000 women with normal renal function showed that ingestion of a diet with a higher acidproducing potential resulted in lower bone mineral density and forearm bone mass (after adjustment for age, weight, height, and menstrual status) than that found in those ingesting a diet with a lower acid-producing potential [54].

\section{Increased muscle wasting}

Muscle mass declines in patients with CKD [55]. Although this effect may be related to nutritional deprivation or exposure to a uremic milieu, metabolic acidosis has also been implicated as an important factor. May et al. [56] were the first to demonstrate that mild metabolic acidosis (serum $\left[\mathrm{HCO}_{3}{ }^{-}\right]$of approx. $20 \mathrm{mEq} / \mathrm{l}$ ) in rats with $\mathrm{CKD}$ was associated with increased degradation of muscle protein without any alteration in protein synthesis [56-58]. The increased protein degradation was due to the increased transcription of genes encoding proteins of the ATPdependent ubiquitin-proteasome pathway, resulting in increased activity of the ATP-dependent ubiquitin-proteasome system [59]. Of interest, activation of muscle protein degradation requires endogenous glucorticoids $[56,57,60$, 61]. Recent studies have identified the dependency on glucocorticoids to increase muscle protein wasting as a non-genomic mechanism by which the glucocorticoid receptor sequesters phosphatidylinositol-3-kinase to interrupt insulin-IGF-1 signaling [62].

In several studies, amelioration of metabolic acidosis by the provision of base to patients with CKD before or after initiation of maintenance dialysis decreased the rate of protein degradation and urea generation, resulting in improved protein balance and increased muscle mass [63-67].

Similar to bone disease, some evidence suggests that a detectable fall in serum $\left[\mathrm{HCO}_{3}{ }^{-}\right]$may not be necessary to stimulate muscle degradation. Neutralization of the endogenous acid load by administering potassium bicarbonate to women with normal renal function and normal acidbase parameters led to a significant reduction in urinary nitrogen loss, suggesting that this maneuver reduced muscle degradation [68].

\section{Reduced albumin synthesis}

Experimental induction of metabolic acidosis in normal humans for at least 7 days has in some - but not all—such studies caused a reduction in albumin synthesis, thereby predisposing the individual to the development of hypoalbuminemia [22,69]. Indeed, analysis of more than 1500 patients $>20$ years of age who participated in the NHANES III study revealed that the age-adjusted odds ratio of serum $\left[\mathrm{HCO}_{3}{ }^{-}\right]$for hypoalbuminemia rose from 1.0 for serum $\left[\mathrm{HCO}_{3}{ }^{-}\right]>28 \mathrm{mEq} / 1$ to 1.54 for serum $\left[\mathrm{HCO}_{3}{ }^{-}\right] \leq 22 \mathrm{mEq} / 1$ [70]. Furthermore, in two studies of adult patients with CKD either prior to or after initiation of chronic maintenance dialysis, improvement of the metabolic acidosis by the provision of base caused the serum albumin concentration to rise and protein catabolic rate to fall [71, 72].

Reduced protein synthesis, increased protein breakdown, and enhanced amino acid oxidation [63, 73, 74] have all been suggested as factors contributing to a reduced serum albumin concentration with metabolic acidosis. A decrease in protein intake might also play a role, although in one study in which dietary intake was examined, no difference in protein intake was found in patients with CKD before or after correction of the acidosis [25].

\section{Accelerating the progression of CKD}

The administration of sodium bicarbonate [75] or sodium citrate [76] to rats with $5 / 6$ nephrectomy attenuated the degree of tubulointerstitial disease and decline in GFR when compared to controls receiving $\mathrm{NaCl}$. The chronic administration of sodium bicarbonate to Han.SPRD rats (an experimental model of polycystic kidney disease) inhibited cystic enlargement and prevented the subsequent development of interstitial inflammation, chronic fibrosis, and uremia. [77]. By contrast, in comparison to a control rat population, there was no improvement in the magnitude of 
proteinuria, fall in GFR, or severity of histological injury in a population of 5/6 nephrectomized rats given base [78]. In another study, the administration of acid to rats with renal failure receiving a high-phosphate diet actually slowed the rate of progression of renal failure [79], an effect attributed to a reduction in the quantity of calcium precipitated in the kidney [80].

Despite these conflicting results from studies in animals, the limited number of studies in humans have supported the potential role of metabolic acidosis in the progression of CKD. In a large cohort of patients with CKD followed at a single medical center, a serum $\left[\mathrm{HCO}_{3}{ }^{-}\right]$of $<22 \mathrm{mEq} / 1$ was associated with a $54 \%$ increased hazard of progression of CKD when compared with a serum $\left[\mathrm{HCO}_{3}{ }^{-}\right]$of $25-$ $26 \mathrm{mEq} / 1$ [81]. In two separate studies, one in patients with hypertensive renal disease [82] and another in patients with CKD of diverse etiology [83], the administration of base slowed the progression of CKD. In the latter study, the rate of decline in GFR in those given bicarbonate was less than half that in the control group. Moreover, the bicarbonate group was less likely to experience a rapid decline in GFR or develop end-stage renal disease.

Three mechanisms have been postulated to explain the acceleration of progression of CKD in response to metabolic acidosis. First, it has been suggested that the increase in renal medullary ammonia concentration resulting from the stimulation of ammonia production by metabolic acidosis activates the alternative complement pathway and causes progressive tubulointerstitial injury [84]. Second, it has been suggested that new bicarbonate synthesized by the kidney in response to acidosis alkalinizes the interstitium and encourages precipitation of calcium in the kidney [85]. Finally, evidence in both animals and humans has been accrued to suggest that increased endothelin production may mediate the tubulointerstitial injury and decline in GFR noted with the metabolic acidosis of CKD $[82,86]$.

Impaired glucose homeostasis

Studies in rats showed that metabolic acidosis was associated with impaired glucose tolerance and insulin resistance [87-90]. In vitro experiments revealed that the insulin resistance was attributed, in part, to $\mathrm{pH}-$ related impaired binding of insulin to its receptors [89, 90]. Experiments in humans with normal renal function using both the euglycemic and hyperglycemic clamp technique revealed that ammonium chloride-induced metabolic acidosis resulted in reduced tissue sensitivity to insulin [91]. Studies in patients with CKD have also demonstrated impaired glucose tolerance and insulin resistance, both prior to and after the initiation of chronic maintenance dialysis $[92,93]$. The effect of uremia on insulin resistance appeared to be related, in part, to metabolic acidosis, because the administration of base to stable hemodialysis patients improved, although it did not normalize, insulin sensitivity [92]. The insulin resistance and glucose intolerance of uremia per se are generally not severe, but it is possible that they contribute to the development of other clinical abnormalities.

Accumulation of $\beta_{2}$-microglobulin

The accumulation of $\beta_{2}$-microglobulin in individuals with CKD contributes to the development of amyloidosis. Amyloid infiltration can cause the carpal tunnel syndrome, bone cysts and, possibly, cardiomyopathy [94]. This accumulation of $\beta_{2}$-microglobulin is primarily related to the number of years on dialysis [94], which has been interpreted as suggesting that the predilection to amyloidosis is due to reduced excretion of $\beta_{2}$-microglobulin and, in the case of hemodialysis, also to chronic exposure of blood to the dialysis membrane.

Metabolic acidosis has been suggested as a possible additional factor in promoting $\beta_{2}$-microglobulin accumulation. First, there is an inverse correlation between serum $\left[\mathrm{HCO}_{3}{ }^{-}\right]$and $\beta_{2}$-microglobulin levels in patients with $\mathrm{CKD}$ [94]. Furthermore, $\beta_{2}$-microglobulin concentrations have been found to be higher in patients dialyzed with acetate who have a lower serum $\left[\mathrm{HCO}_{3}{ }^{-}\right]$than those dialyzed with bicarbonate [94]. How important the contribution of metabolic acidosis to $\beta_{2}$-microglobulin accumulation remains unclear.

\section{Abnormal thyroid function}

Individuals with uremia have low basal metabolic rates. This could be related in part to the associated metabolic acidosis affecting thyroid hormone levels, since ammonium chloride-induced metabolic acidosis has been found to be associated with reduced triiodothyronine (T3) and thyroxine (T4) and elevated thyroid-stimulating hormone levels [23, 95]. Furthermore, correction of metabolic acidosis in patients with CKD causes T3 levels to rise towards normal [95].

\section{Stimulation of inflammation}

Exposure of macrophages to an acidic environment leads to the increased production of tumor necrosis factor $\alpha$ $(\mathrm{TNF} \alpha)$ [96]. In one study, the correction of metabolic acidosis in a small number of patients maintained on chronic ambulatory peritoneal dialysis was associated with a reduction in TNF $\alpha$ levels [67]. Thus, it has been suggested that metabolic acidosis is associated with the stimulation of inflammation and, therefore, that it represents 
a chronic inflammatory state. However, no significant difference was observed in the serum levels of C-reactive protein and interleukin-6 (two biomarkers of inflammation) among three separate groups of dialysis patients with a mean serum $\left[\mathrm{HCO}_{3}{ }^{-}\right]$of $19.2,24.4$, and $27.5 \mathrm{mEql} / \mathrm{l}$, respectively [97]. Further studies of a large number of patients will be needed to determine the relative importance of metabolic acidosis to the genesis of chronic inflammation in patients with CKD.

Development or exacerbation of cardiac disease and increase in mortality

A link between hypobicarbonatemia and the risk of death has been found in patients with CKD, both prior to and after initiation of chronic maintenance dialysis. A retrospective analysis of laboratory data obtained from more than 12,000 hemodialysis patients showed an increased risk of death in patients with a serum $\left[\mathrm{HCO}_{3}{ }^{-}\right]<15-17 \mathrm{mEq} / 1$ [98]. Also, patients with CKD not on dialysis had a greater risk of death when their serum $\left[\mathrm{HCO}_{3}{ }^{-}\right]$was $<22 \mathrm{mEq} / 1$ [4]. Because cardiovascular disease is the most common cause of death in patients with $\mathrm{CKD}$, it is reasonable to speculate that metabolic acidosis increases the prevalence or severity of cardiovascular disease. This hypothesis is further supported by strong evidence that inflammation plays an important role in the genesis and progression of atherosclerotic heart disease.

\section{Treatment of the metabolic acidosis of CKD}

As summarized above, the predominance of evidence indicates that the chronic metabolic acidosis of CKD is deleterious and that its improvement imparts benefit. Therefore, base therapy to ameliorate the acidosis appears to be indicated. Consequently, the major issues to be addressed are: What modality of therapy should be used? What serum $\left[\mathrm{HCO}_{3}{ }^{-}\right]$should be targeted? What measures should be taken to prevent any complications of therapy?

In patients with $\mathrm{CKD}$ not on dialysis, serum $\left[\mathrm{HCO}_{3}{ }^{-}\right]$ can be raised by administering base in the form of oral bicarbonate or organic anions that are metabolized to bicarbonate, such as citrate (Shohl's solution, $1 \mathrm{ml}$ equivalent to $1 \mathrm{mEq}$ of base as sodium citrate). The former treatment often produces abdominal bloating as $\mathrm{CO}_{2}$ is formed from the combination of $\mathrm{HCO}_{3}{ }^{-}$with gastric acid and, therefore, patients usually prefer the latter formulation. The quantity of base required to raise serum $\left[\mathrm{HCO}_{3}{ }^{-}\right]$by a given amount can be estimated from the following formula: desired $\left[\mathrm{HCO}_{3}{ }^{-}\right]-$measured $\left[\mathrm{HCO}_{3}{ }^{-}\right] \times \mathrm{HCO}_{3}{ }^{-}$space, where bicarbonate space is approximately $50 \% \mathrm{~b}$. wt $(\mathrm{kg})$.
Although not proven, it has been postulated that metabolic acidosis depletes bone reserves of base in bone [99] and, therefore, that a portion of the base administered to patients with CKD may be required to replete bone base reserves. Once serum $\left[\mathrm{HCO}_{3}{ }^{-}\right]$reaches the desired level, the quantity of base given can be reduced to the minimal necessary to maintain a stable serum $\left[\mathrm{HCO}_{3}{ }^{-}\right]$; theoretically, this amount is equal to the endogenous net acid load minus net acid secretion. This can vary depending on protein intake and residual renal function present, but in a $70-\mathrm{kg}$ man this will be approximately $20-60 \mathrm{mEq} /$ day. If substantial urinary bicarbonate wasting is present, of course it will be necessary to administer greater quantities of base. This will be evidenced by the appearance of bicarbonate in the urine prior to normalization of serum $\left[\mathrm{HCO}_{3}{ }^{-}\right]$.

In patients with end-stage renal disease on hemodialysis, predialysis serum $\left[\mathrm{HCO}_{3}{ }^{-}\right]$can be normalized in the majority of patients using a dialysate containing 39$40 \mathrm{mEq} / 1$ of $\mathrm{HCO}_{3}^{-}$[100]. In patients who fail to raise serum $\left[\mathrm{HCO}_{3}{ }^{-}\right]$to the desired level in response to the higher dialysate $\mathrm{HCO}_{3}{ }^{-}$, the addition of oral base is usually effective. In the majority of continuous ambulatory peritoneal dialysis patients, acid-base parameters can be maintained within the normal range with the conventional $35 \mathrm{mEq} / 1$ lactate-based dialysate, although some studies suggest a better correction of acidosis with the $25 \mathrm{mEq} / \mathrm{l}$ bicarbonate $/ 15 \mathrm{mEq} / 1$ lactate dialysate [101]. As with hemodialysis patients, those who fail to raise serum $\left[\mathrm{HCO}_{3}{ }^{-}\right]$to the desired level will usually respond to the addition of oral base.

The serum $\left[\mathrm{HCO}_{3}{ }^{-}\right]$to be targeted in patients with $\mathrm{CKD}$ prior to and after the initiation of maintenance dialysis is not clear. At the present time, the National Kidney Foundation Kidney Disease Outcomes Quality Initiative (NKF KDOQI) recommends raising serum $\left[\mathrm{HCO}_{3}{ }^{-}\right]$to $\geq 22 \mathrm{mEq} / 1$ [102], and the Care of Australians with Renal Impairment (CARI) guidelines recommend raising serum $\left[\mathrm{HCO}_{3}{ }^{-}\right]$to $>22 \mathrm{mEq} / 1$ [103]. Finally, the European Pediatric Dialysis Working Group in its guidelines for the prevention and treatment of renal osteodystropy of CKD [104] recommends that metabolic acidosis should be corrected to the range of normal of the local laboratory. All of these recommendations are based on expert opinion rather than analysis of carefully controlled randomized studies. As mentioned previously, experimental results suggest that even mild hypobicarbonatemia might be deleterious; therefore, we recommend raising serum $\left[\mathrm{HCO}_{3}{ }^{-}\right]$into the mean normal values (i.e. $24-25 \mathrm{mEq} / 1$ in adults and $22-23 \mathrm{mEq} / 1$ in children). This is particularly important in pediatric patients, given the relatively short window of time available for continuing growth. On the other hand, the physician should not attempt to raise serum $\left[\mathrm{HCO}_{3}{ }^{-}\right]$above the normal range as this could lead to 
complications of treatment and, in addition, it has not yet been proven to be of benefit.

Potential complications of base therapy in patients not on dialysis include volume overload, congestive heart failure, and exacerbation of pre-existing hypertension-all complications due to sodium retention. These complications can be avoided by the concomitant administration of diuretics or the use of calcium carbonate or calcium citrate to provide the base. Moreover, sodium retention is less when the sodium is given as a non-chloride-containing salt, particularly if sodium chloride restriction is severe [105]. There is the ever-present potential to exacerbate vascular calcifications by decreasing the solubility of calcium phosphate if alkalemia occurs. Studies performed in dialysis patients in whom blood $\mathrm{pH}$ rose into the alkalemic range revealed no change in one of the risk factors for metastatic calcification as determined by the relative saturation ratio of hydroxyapatite [100] or the calculated concentration product ratio for hydroxyapatite formation [106]. However, the author of the latter study suggested that if serum phosphorus concentration were to rise a few hours after the completion of dialysis, this ratio might be elevated enough to favor calcifications. Finally, the administration of citrate can enhance aluminum absorption [107], but this problem can be prevented by the avoidance of aluminum binders.

The recommendation by the NKF to limit daily calcium intake has resulted in a shift to the greater use of noncalcium-containing phosphate binders, such as Renagel (sevelamer hydrochloride). However, a fall in serum $\left[\mathrm{HCO}_{3}{ }^{-}\right]$has been detected in both adults [108] and children [109] receiving Renagel. An additional preparation, sevelamer carbonate (instead of hydrochloride), has been shown to be effective in controlling serum phosphorus while raising serum $\left[\mathrm{HCO}_{3}{ }^{-}\right]$in both children [110] and adults [111] with CKD. This preparation may therefore prove to be a reasonable alternative. If the latter preparation is not available, base administration might have to be increased to prevent or treat metabolic acidosis. On the other hand, if the individual is receiving calcium carbonate, calcium citrate, or sevelamer carbonate, base administration may have to be reduced.

In summary, the metabolic acidosis of CKD is associated with a myriad of complications which appear to respond to base therapy. Therefore, base therapy should be administered to all patients with metabolic acidosis. We recommend administering sufficient base to raise serum $\left[\mathrm{HCO}_{3}{ }^{-}\right]$ into the mean normal values (i.e. $24-25 \mathrm{mEq} / 1$ in adults and $22-23 \mathrm{mEq} / 1$ in children), while carefully monitoring patients for possible adverse effects. Blood samples for the determination of serum $\left[\mathrm{HCO}_{3}{ }^{-}\right]$should be obtained prior to taking the daily alkali dose so as not to produce an erroneous value.
Our recommendations for the treatment of the metabolic acidosis of CKD can be summarized as follows:

- Administer base early in the course of CKD at the first appearance of hypobicarbonatemia.

- Calculate bicarbonate requirements in patients with $\mathrm{CKD}$ not on dialysis using formula: desired $\left[\mathrm{HCO}_{3}{ }^{-}\right]-$ measured $\left[\mathrm{HCO}_{3}{ }^{-}\right] \times \mathrm{HCO}_{3}{ }^{-}$space, where bicarbonate space is approximately $50 \%$ body weight.

- Use sodium citrate (Shohl's solution) if patients are bothered by gastric bloating with sodium bicarbonate.

- Once serum $\left[\mathrm{HCO}_{3}{ }^{-}\right]$is stable, reduce base administration to the level required to neutralize endogenous acid load.

- If urinary bicarbonate wasting is present, consider this in estimating base requirements.

- Monitor patient for volume overload or exacerbation of hypertension and treat accordingly.

- In hemodialysis patients, use a dialysate base concentration of $39 \mathrm{mEq} / \mathrm{l}$; add oral base, as needed.

- In continuous ambulatory peritoneal dialysis patients, use a dialysate containing $35 \mathrm{mEq} / \mathrm{l}$ lactate. If not effective, change to a dialysate containing $25 \mathrm{mEq} / \mathrm{l}$ bicarbonate/ $15 \mathrm{mEq} / \mathrm{l}$ lactate dialysate and add oral base, as needed.

- Avoid hyperphosphatemia and hypercalcemia if possible to minimize the risk of metastatic calcifications.

Acknowledgments This work was supported in part by research funds from the Veterans Administration (JAK).

Open Access This article is distributed under the terms of the Creative Commons Attribution Noncommercial License which permits any noncommercial use, distribution, and reproduction in any medium, provided the original author(s) and source are credited.

\section{References}

1. Kraut JA, Kurtz I (2005) Metabolic acidosis of CKD: Diagnosis, clinical characteristics, and treatment. Am J Kidney Dis 45:978-993

2. Hakim RM, Lazarus JM (1988) Biochemical parameters in chronic renal failure. Am J Kidney Dis 11:238-247

3. Kopple JD, Kalantar-Zadeh K, Mehrotra R (2005) Risks of chronic metabolic acidosis in patients with chronic kidney disease. Kidney Int 67:S21-S27

4. Kovesdy CP, Anderson JE, Kalantar-Zadeh K (2009) Association of serum bicarbonate levels with mortality in patients with nondialysis-dependent CKD. Nephrol Dial Transplant 24:1232-1237

5. Halperin ML, Jungas RL (1983) Metabolic production and renal disposal of hydrogen ions. Kidney Int 24:709-713

6. Rodriguez-Soriano J, Vallo A (1990) Renal tubular acidosis. Pediatr Nephrol 4:268-275

7. Chan RSM, Woo J, Chan DCC, Cheung CSK, Lo DHS (2009) Estimated net endogenous acid production and intake of bone health-related nutrients in Hong Kong Chinese adolescents. Eur J Clin Nutr 63:505-512

8. Uribarri J, Douyon H, Oh MS (1995) A re-evaluation of the urinary parameters of acid production and excretion in patients with chronic renal acidosis. Kidney Int 47:624-627 
9. Uribarri J, Zia M, Mahmood J, Marcus RA, Oh MS (1998) Acid production in chronic hemodialysis patients. J Am Soc Nephrol 9:112-120

10. Lameire N, Matthys E (1986) Influence of progressive salt restriction on urinary bicarbonate wasting in uremic acidosis. Am J Kidney Dis 8:151-158

11. Schwartz WB, Hall PW, Hays RM, Relman AS (1959) On the mechanism of acidosis in chronic renal disease. J Clin Invest 38:39-52

12. Goodman AD, Lemann J Jr, Lennon EJ, Relman AS (1965) Production, excretion, and net balance of fixed acid in patients with renal acidosis. J Clin Invest 44:495-506

13. Lemann J Jr, Bushinsky DA, Hamm LL (2003) Bone buffering of acid and base in humans. Am J Physiol 285:F811-F832

14. Kraut JA (2000) Disturbances of acid-base balance and bone disease in end-stage renal disease. Semin Dial 13:261-265

15. Hsu CY, Chertow GM (2002) Elevations of serum phosphorus and potassium in mild to moderate chronic renal insufficiency. Nephrol Dial Transplant 17:1419-1425

16. Widmer B, Gerhardt RE, Harrington JT, Cohen JJ (1979) Serum electrolytes and acid base composition. The influence of graded degrees of chronic renal failure. Arch Intern Med 139:10991102

17. Schambelan M, Sebastian A, Biglieri EG (1980) Prevalence, pathogenesis, and functional significance of aldosterone deficiency in hyperkalemic patients with chronic renal insufficiency. Kidney Int 17:89-101

18. Elkington JR (1962) Hydrogen ion turnover in health and disease. Ann Intern Med 57:660-684

19. Wallia R, Greenberg A, Piraino B, Mitro R, Puschett JB (1986) Serum electrolyte patterns in end-stage renal disease. Am J Kidney Dis 8:98-104

20. Sebastian A, Schambelan M, Lindenfeld S, Morris RC (1977) Amelioration of metabolic acidosis with fludrocortisone therapy in hyporeninemic hypoaldosteronism. N Engl J Med 297:576-583

21. Reaich D, Channon SM, Scrimgeour CM, Goodship THJ (1992) Ammonium chloride-Induced acidosis increases protein breakdown and amino acid oxidation in humans. Am J Physiol 263: E735-E739

22. Ballmer PE, McNurlan MA, Hulter HN, Anderson SE, Garlick PJ, Krapf R (1995) Chronic metabolic acidosis decreases albumin synthesis and induces negative nitrogen balance in humans. J Clin Invest 95:39-45

23. Brungger M, Hulter HN, Krapf R (1997) Effect of chronic metabolic acidosis on thyroid hormone homeostasis in humans. Am J Physiol 272:F648-F653

24. Roberts RG, Redfern CPF, Graham KA, Bartlett K, Wilkinson R, Goodship TH (2002) Sodium bicarbonate treatment and ubiquitin gene expression in acidotic human subjects with chronic renal failure. Eur J Clin Invest 32:488-492

25. Roberts RG, Gilmour ER, Goodship TH (1996) The correction of acidosis does not increase dietary protein intake in chronic renal failure patients. Am J Kidney Dis 28:350-353

26. Chauveau P, Fouque D, Combe C, Laville M, Canaud B, Azar R, Cano N, Aparicio M, Leverve X (2000) Acidosis and nutritional status in hemodialyzed patients. Semin Dial 13:241-246

27. Graham KA, Reaich D, Channon SM, Downie S, Goodship TH (1997) Correction of acidosis in hemodialysis decreases whole body protein degradation. J Am Soc Nephrol 8:632-637

28. Graham KA, Hoenich NA, Tarbit M, Ward MK, Goodship TH (1997) Correction of acidosis in hemodialysis patients increases the sensitivity of the parathyroid glands to calcium. J Am Soc Nephrol 8:627-631

29. Lefebvre A, DeVernejoul MC, Gueris J, Goldfarb B, Graulet AM, Morieux C (1989) Optimal correction of acidosis changes progression of dialysis osteodystrophy. Kidney Int 36:1112-1118
30. Roderick P, Willis NS, Blakeley S, Jones C, Tomson C (2007) Correction of chronic metabolic acidosis for chronic kidney disease patients. Cochrane Database of Syst Rev CD001890

31. Bushinsky DA (1999) Nephrology forum: The contribution of acidosis to renal osteodystrophy. Kidney Int 47:1816-1832

32. Krieger NS, Sessler NE, Bushinsky DA (1992) Acidosis inhibits osteoblastic and stimulates osteoclastic activity in vitro. Am J Physiol 262:F442-F448

33. Kraut JA, Mishler DR, Singer FR, Goodman WG (1986) The effects of metabolic acidosis on bone formation and bone resorption in the rat. Kidney Int 30:694-700

34. Chan YL, Sardie E, Mason RS, Posen S (1985) The effect of metabolic acidosis on vitamin D metabolism and bone histology in uremic rats. Calcif Tissue Int 37:158-164

35. Lu KC, Lin SH, Yu FC, Chyr SH, Shieh SD (1995) Influence of metabolic acidosis on serum 1, $25(\mathrm{OH}) 2 \mathrm{D} 3$ levels in chronic renal failure. Miner Electrolyte Metab 21:398-402

36. Coe FL, Firpo DJ, Hollandsworth L, Segil L, Canterbury JM, Reiss E (1975) Effect of acute and chronic metabolic acidosis on serum immunoreactive parathyroid hormone in man. Kidney Int 8:263-273

37. Martin KJ, Freitag JJ, Bellorin-Font E, Conrades MB, Klahr S, Slatopolsky E (1980) The effect of acute acidosis on the uptake of parathyroid hormone and the production of adenosine 3 ', 5'monophosphate by isolated perfused bone. Endocrinology 106:1607-1611

38. Quinn SJ, Bai M, Brown EM (2004) pH sensing by the calciumsensing receptor. J Biol Chem 279:37241-37249

39. Barzel US, Jowsey J (1969) The effect of chronic acid and alkali administration on bone turnover in adult rats. Clin Sci 36:517-524

40. Cochran M, Wilkinson R (1975) Effect of correction of metabolic acidosis on bone mineralization rates in patients with renal osteomalacia. Nephron 15:98-110

41. Coen G, Manni M, Addari O, Ballanti P, Pasquali M, Chicca S, Mazzaferro S, Napoletano I, Sardella D, Bonucci E (1995) Metabolic acidosis and osteodystrophic bone disease in predialysis chronic renal failure:effect of calcitriol treatment. Miner Electrolyte Metab 21:375-382

42. Coen G, Mazzaferro S, Ballanti P (1996) Renal bone disease in 76 patients with varying degrees of predialysis chronic renal failure: a cross sectional study. Nephrol Dial Transplant 11:813-819

43. Kraut JA (1995) The role of metabolic acidosis in the pathogenesis of renal osteodystrophy. Adv Ren Replace Ther 2:40-51

44. Lemann J Jr, Adams ND, Wilz DR, Brenes LG (2000) Acid and mineral balances and bone in familial proximal renal tubular acidosis. Kidney Int 58:1267-1277

45. Bergqvist AGC, Schall JI, Stallings VA, Zemel BS (2008) Progressive bone mineral content loss in children with intractable epilepsy treated with the ketogenic diet. Am J Clin Nutr 88:1678-1684

46. McSherry E, Morris RC Jr (1978) Attainment and maintenance of normal stature with alkali therapy in infants and children with classic renal tubular acidosis. J Clin Invest 61:509-527

47. Domrongkitchaiporn S, Pongskul C, Sirikulchayanonta V, Stitchantrakul W, Leeprasert V, Ongphiphadhanakul B, Radinahamed P, Rajatanavin R (2002) Bone histology and bone mineral density after correction of acidosis in distal renal tubular acidosis. Kidney Int 62:2160-2166

48. Carbajo E, Lopez JM, Santos F, Ordonez FA, Nino P, Rodriguez J (2001) Histologic and dynamic changes induced by chronic metabolic acidosis in the rat growth plate. J Am Soc Nephrol 12:1228-1234

49. Mahan JD, Warady BA (2006) Assessment and treatment of short stature in pediatric patients with chronic kidney disease: a consensus statement. Pediatr Nephrol 21:917-930 
50. Kleinknecht C, Maniar S, Zhou XA, Motel V, Laouari D, Yvert JP, Dechaux M (1996) Acidosis prevents growth hormone-induced growth in experimental uremia. Pediatr Nephrol 10:256-260

51. Challa A, Chan W, Krieg RJJ, Thaber MA, Liu F, Hintz RL, Chan JC (1993) Effect of metabolic acidosis on the expression of insulin-like growth factor and growth hormone receptor. Kidney Int 44:1224-1227

52. Ordonez FA, Santos F, Martinez V, Garcia E, Fernandez P, Rodriguez J, Fernandez M, Alvarez J, Ferrando S (2000) Resistance to growth hormone and insulin-like growth factor-I in acidotic rats. Pediatr Nephrol 14:720-725

53. Sebastian A, Harris ST, Ottaway JH, Todd KM, Morris RC Jr (1994) Improved mineral balance and skeletal metabolism in postmenopausal women treated with potassium bicarbonate. $\mathrm{N}$ Engl J Med 330:1776-1781

54. New SA, Macdonald HM, Campbell MK, Martin JC, Garton MJ, Robins SP, Reid DM (2004) Lower estimates of net endogenous noncarbonic acid production are positively associated with indexes of bone health in premenopausal and perimenopausal women. Am J Clin Nutr 79:131-138

55. Coles GA (1972) Body composition in chronic renal failure. Q J Med 41:25-47

56. May RC, Kelly RA, Mitch WE (1987) Mechanisms for defects in muscle protein metabolism in rats with chronic uremia: the influence of metabolic acidosis. J Clin Invest 79:1099-2003

57. Mitch WE, Price SR (2003) Mechanisms activating proteolysis to cause muscle atrophy in catabolic conditions. J Ren Nutr $13: 149-152$

58. Mitch WE (1998) Mechanisms causing loss of lean body mass in kidney disease 282. Am J Clin Nutr 67:359-366

59. Bailey JL, Wang XN, England BK, Price SR, Ding XY, Mitch WE (1996) The acidosis of chronic renal failure activates muscle proteolysis in rats by augmenting transcription of genes encoding proteins of the ATP-dependent ubiquitin-proteasome pathway. J Clin Invest 97:1447-1453

60. Price SR, England BK, Bailey JL, Vanvreede K, Mitch WE (1994) Acidosis and glucocorticoids concomitantly Increase ubiquitin and proteasome subunit messenger rnas in rat muscle. Am J Physiol 36:C955-C960

61. May RC, Bailey JL, Mitch WE, Masud T, England BK (1996) Glucocorticoids and acidosis stimulate protein and amino acid catabolism in vivo. Kidney Int 49:679-683

62. Hu ZY, Wang HL, Lee IH, Du J, Mitch WE (2009) Endogenous glucocorticoids and impaired insulin signaling are both required to stimulate muscle wasting under pathophysiological conditions in mice. J Clin Invest 119:3059-3069

63. Reaich D, Channon SM, Scrimgeour CM, Daley SE, Wilkinson R, Goodship TH (1993) Correction of acidosis in humans with Crf decreases protein degradation and amino acid oxidation. Am J Physiol 265:E230-E235

64. Williams AJ, Dittmer ID, McArley A, Clarke J (1997) High bicarbonate dialysate in haemodialysis patients: effects on acidosis and nutritional status. Nephrol Dial Transplant 12:2633-2637

65. Lim VS, Yarasheski KE, Flanigan MJ (1998) The effect of uraemia, acidosis, and dialysis treatment on protein metabolism: a longitudinal leucine kinetic study. Nephrol Dial Transplant 13:1723-1730

66. Papadoyannakis NJ, Stefanidis CJ, McGeown M (1984) The effect of the correction of metabolic acidosis on nitrogen and protein balance of patients with chronic renal failure. Am J Clin Nutr 40:623-627

67. Pickering WP, Price SR, Bircher G, Marinovic AC, Mitch WE, Walls J (2002) Nutrition in CAPD: Serum bicarbonate and the ubiquitin-proteasome system in muscle. Kidney Int 61:12861292
68. Frasetto L, RCj M, Sebastian A (1997) Potassium bicarbonate reduces urinary nitrogen excretion in postmenopausal women. J Clin Endocrinol Metab 82:254-259

69. Kleger GR, Turgay M, Imoberdorf R, McNurlan MA, Garlick PJ, Ballmer PE (2001) Acute metabolic acidosis decreases muscle protein synthesis but not albumin synthesis in humans. Am J Kidney Dis 38:1199-1207

70. Eustace JA, Astor B, Muntner PM, Ikizler TA, Coresh J (2004) Prevalence of acidosis and inflammation and their association with low serum albumin in chronic kidney disease. Kidney Int 65:1031-1040

71. Movilli E, Zani R, Carli O, Sangalli L, Pola A, Camerini C, Cancarini GC, Scolari F, Feller P, Maiorca R (1998) Correction of metabolic acidosis increases serum albumin concentrations and decreases kinetically evaluated protein intake in haemodialysis patients: a prospective study. Nephrol Dial Transplant 13:1719-1722

72. Verove C, Maisonneuve N, El Azouzi A, Boldron A, Azar R (2002) Effect of the correction of metabolic acidosis on nutritional status in elderly patients with chronic renal failure. J Ren Nutr 12:224-228

73. Price SR, Reaich D, Marinovic AC, England BK, Bailey JL, Caban R, Mitch WE, Maroni BJ (1998) Mechanisms contributing to muscle wasting in acute uremia: Activation of amino acid catabolism. J Am Soc Nephrol 9:439-443

74. Kalantar-Zadeh K, Mehrotra R, Fouque D, Kopple JD (2004) Metabolic acidosis and malnutrition-inflammation complex syndrome in chronic renal failure. Semin Dial 17:455-465

75. Nath KA, Hostetter MK, Hostetter TH (1985) Pathophysiology of chronic tubulointerstitial disease in rats. Interactions of dietary acid load, ammonia, and complement component C3. J Clin Invest 76:667-675

76. Gadola L, Noboa $\mathrm{O}$, Marquez $\mathrm{MN}$, Rodriguez $\mathrm{MJ}$, Nin $\mathrm{N}$, Boggia J, Ferreiro A, Garcia S, Ortega V, Musto ML, Ponte P, Sesser P, Pizarrosa C, Ravaglio S, Vallega A (2004) Calcium citrate ameliorates the progression of chronic renal injury. Kidney Int 65:1224-1230

77. Torres VE, Cowley BDJ, Branden MG, Yoshida I, Gattone VH (2001) Long-term ammonium chloride or sodium bicarbonate treatment in two models of polycystic kidney disease. Exp Nephrol 9:171-180

78. Throssel D, Brown J, Harris KP, Walls J (1995) Metabolic acidosis does not contribute to chronic renal injury in the rat. Clin Sci 89:643-650

79. Jara A, Felsenfeld AJ, Bover J, Kleeman CR (2000) Chronic metabolic acidosis in azotemic rats on a high phosphate diet halts the progression of renal disease. Kidney Int 58:10231032

80. Jara A, Chacon C, Ibaceta M, Valdivieso A, Felsenfeld AJ (2004) Effect of ammonium chloride and dietary phosphorus in the azotaemic rat. Part II - kidney hypertrophy and calcium deposition. Nephrol Dial Transplant 19:1993-1998

81. Shah SN, Abramowitz M, Hostetter TH, Melamed ML (2009) Serum bicarbonate levels and the progression of kidney disease: a cohort study. Am J Kidney Dis 54:270-277

82. Phisitkul S, Khanna A, Simoni A, Broglio K, Rajab MH, Wesson DE (2010) Amelioration of metabolic acidosis in patients with low GFR reduced kidney endothelin production and kidney injury, and better preserved GFR. Kidney Int 77:617-623

83. De Brito-Ashurst I, Varagunam M, Raftery MJ, Yaqoob MM (2009) Bicarbonate supplementation slows progression of CKD and improves nutritional status. J Am Soc Nephrol 20:20752084

84. Nath KA, Hostetter MK, Hostetter TH (1991) Increased ammoniagenesis as a determinant of progressive renal injury. Am J Kidney Dis 17:654-657 
85. Halperin ML, Ethier JH, Kamel KS (1989) Ammonium excretion in chronic metabolic acidosis: benefits and risks. Am J Kidney Dis 14:267-271

86. Phisitkul S, Hacker C, Simoni J, Tran RM, Wesson DE (2008) Dietary protein causes a decline in the glomerular filtration rate of the remnant kidney mediated by metabolic acidosis and endothelin receptors. Kidney Int 73:192-199

87. Cuthbert C, Alberti KG (1978) Acidemia and insulin resistance in diabetic ketoacidotic rat. Metabolism 27:1903-1916

88. Whittaker J, Cuthbert C, Hamond V, Alberti KG (1981) Impaired insulin binding to isolated adipocytes in experimental diabetic ketoacidosis. Diabetologia 21:563-568

89. Whittaker J, Cuthbert C, Hammond VA, Alberti KG (1982) The effects of metabolic acidosis in vivo on insulin binding to isolated rat adipocytes. Metabolism 31:553-557

90. Igarashi M, Yamatani K, Fukase N, Daimon M, Ohnuma H, Ogawa A, Tominaga M, Sasaki H (1993) Effect of acidosis on insulin binding and glucose uptake in isolated rat adipocytes. Tohoku J Exp Med 169:205-213

91. Defronzo RA, Beckles AD (1979) Glucose intolerance following chronic metabolic acidosis in man. Am J Physiol 236:E328-E334

92. Mak RH (1998) Effect of metabolic acidosis on insulin action and secretion in uremia. Kidney Int 54:603-607

93. Mak RH (2008) Insulin and its role in chronic kidney disease. Pediatr Nephrol 23:355-362

94. Sonikian M, Gogusev J, Zingraff J, Loric S, Quednau B, Bessou G, Siffert W, Drueke TD, Reusch H, Luft FC (1996) Potential effect of metabolic acidosis on beta2-microglobulin generation: In vivo and in vitro studies. J Am Soc Nephrol 7:350-356

95. Wiederkehr MR, Kalogiros J, Krapf R (2004) Correction of metabolic acidosis improves thyroid and growth hormone axes in haemodialysis patients. Nephrol Dial Transplant 19:1190-1197

96. Bellocq A, Suberville S, Philippe C, Bertrand F, Perez J, Fouqueray B, Cherqui G, Baud L (1998) Low environmental $\mathrm{pH}$ is responsible for the induction of nitric-oxide synthase in macrophages - evidence for involvement of nuclear factor-kappa B activation. J Biol Chem 273:5086-5092

97. Lin SH, Lin YF, Chin HM, Wu CC (2002) Must metabolic acidosis be associated with malnutrition in haemodialysed patients? Nephrol Dial Transplant 17:2006-2010

98. Bommer J, Locatelli F, Satayathum S, Keen ML, Goodkin DA, Saito A, Akiba T, Port FK, Young EW (2004) Association of predialysis serum bicarbonate levels with risk of mortality and hospitalization in the Dialysis Outcomes and Practice Patterns Study (DOPPS). Am J Kidney Dis 44:661-671
99. Burnell JM (1971) Changes in bone sodium and carbonate in metabolic acidosis and alkalosis in dog. J Clin Invest 50:327331

100. Harris DC, Yuill E, Chesher DW (1995) Correcting acidosis in hemodialysis: effect on phosphate clearance and calcification risk. J Am Soc Nephrol 6:1607-1612

101. Carrasco AM, Rubio MAB, Tomero JAS, Giron FF, Rico MG, Gilsanz GD, Perpen AF, Ramon RG, Bueno IF, Tranaeus A, Faict D, Hopwood A (2001) Acidosis correction with a new $25 \mathrm{mmol} / \mathrm{L}$ bicarbonate $/ 15 \mathrm{mmol} / \mathrm{L}$ lactate peritoneal dialysis solution. Perit Dial Int 21:546-553

102. National Kidney Foundation (2000) K/DOQI: Clinical practice guidelines for nutrition in chronic renal failure. Am J Kidney Dis 35:S1-S140

103. Voss D, Hodson E, Crompton C (2007) Nutrition and growth in kidney disease CARI guidelines. Aust Fam Physician 36:253254

104. Klaus G, Watson A, Edefonti A, Fischbach M, Ronnholm K, Schaefer F, Simkova E, Stefanidis CJ, Strazdins V, Vande Walle J, Schroder C, Zurowska A, Ekim M (2006) Prevention and treatment of renal osteodystrophy in children on chronic renal failure: European guidelines. Pediatr Nephrol 21:151-159

105. Husted FC, Nolph KD (1977) $\mathrm{Na} \mathrm{HCO}_{3}$ and $\mathrm{NaCl}$ tolerance in chronic renal failure. Clin Nephrol 7:21-25

106. Kirschbaum B (2004) Effect of high bicarbonate hemodialysis on ionized calcium and risk of metastatic calcification. Clin Chim Acta 343:231-236

107. Coburn JW, Mischel MG, Goodman WG, Salusky IB (1991) Calcium citrate markedly enhances aluminum absorption from aluminum hydroxide. Am J Kidney Dis 17:708-711

108. Brezina B, Qunibi WY, Nolan CR (2004) Acid loading during treatment with sevelamer hydrochloride: mechanisms and clinical implications. Kidney Int 66:S39-S45

109. Pieper AK, Haffner D, Hoppe B, Dittrich K, Offner G, Bonzel KE, John U, Frund S, Klaus G, Stubinger A, Duker G, Querfeld U (2006) A randomized crossover trial comparing sevelamer with calcium acetate in children with CKD. Am J Kidney Dis 47:625-635

110. Gonzalez E, Schomberg J, Amin N, Salusky IB, Zaritsky J (2010) Sevelamer carbonate increases serum bicarbonate in pediatric dialysis patients. Pediatr Nephrol 25:373-375

111. Delmez J, Block G, Robertson J, Chasan-Taber S, Blair A, Dillon M, Bleyer AJ (2007) A randomized, double-blind, crossover design study of sevelamer hydrochloride and sevelamer carbonate in patients on hemodialysis. Clin Nephrol 68:386-391 